\title{
39. DANIAN CALCISPHAERULIDAE OF DSDP LEG 35, SITE 323, SOUTHEAST PACIFIC OCEAN
}

\author{
Fred Rögl, Geology Department, Museum of Natural History, Vienna, Austria
}

\section{INTRODUCTION}

Site 323 of Leg 35 was drilled in the Southeast Pacific Basin (lat $63^{\circ} 40.84^{\prime} \mathrm{S}$, long $97^{\circ} 59.69^{\prime} \mathrm{W}$ ) in a water depth of 4993 meters. The hole penetrated 731 meters of sediments and basalt of which the uppermost 500 meters are diatomaceous clay and claystone of Miocene and Pliocene age. The underlying gray claystones and siltstones are barren of biogenic silica. Cores 11 to 13 $(550-626.5 \mathrm{~m})$ are ?Oligocene to early Miocene in age based on determinations from arenaceous foraminifera. No age determination was made on Core 14 (636-645.5 $\mathrm{m})$. Within this core the lithology changes downhole from claystones and siltstones to brown Fe-claystone. The upper part of Core 15 yields a fauna of Paleogene arenaceous foraminifera. An age assignment within the Paleogene is not possible.

The lower part of Core 15 to the upper part of Core 16 $(662-667 \mathrm{~m})$ contains calcareous foraminifera and a rich occurrence of Calcisphaerulids. ${ }^{1}$ This unit is a 5 -meter layer of brown Danian nannofossil claystone. The underlying brown claystone down to basement at 701 meters subbottom yields only fish teeth, a sparse fauna of arenaceous foraminifera, and in the lower part, Cretaceous radiolarians and a Maestrichtian nannoflora.

The Danian sediments in Cores 15 and 16 have a fairly rich fauna of calcareous and arenaceous benthonic foraminifera and contain more than $50 \%$ planktonic foraminifera. In some samples, a large part of the residue coarser than $44 \mu \mathrm{m}$ consists of Calcisphaerulidae.

The plankton/benthos ratio and the composition of the benthonic fauna indicate deposition in upper to middle bathyal depths of about 1500-2000 meters. The stratigraphic position of the section is early Paleocene, Danian. According to Haq (this volume), the section falls in the upper part of the nannoplankton Cruciplacolithus tenuis and Chiasmolithus danicus zones. The planktonic foraminifera are of the Globigerina edita Zone (Rögl, this volume).

The samples were washed through a 325 -mesh (44 $\mu \mathrm{m})$ sieve and the isolated Calcisphaerulidae were investigated under the scanning electron microscope (SEM) as described by Bolli (1974). The figured specimens are deposited at the Museum of Natural History, Basel, under the numbers C31278-31314.

\section{SYSTEMATIC DESCRIPTION}

The Danian specimens in the investigated samples belong to the genus Pithonella, following the systematic study on Calcisphaerulidae

'The systematic position of Calcisphaerulidae is uncertain, but it is probably related to some fossil group of planktonic algae. from the Indian Ocean, DSDP Leg 27 (Bolli, 1974). All forms are unilocular with a globular, ovoid, or spindle-shaped elongated test. Most of them have a simple circular aperture varying in size. The wall consists of one or two layers of small calcite crystals. The diameter of most of the specimens is between $50-70 \mu \mathrm{m}$, but a group of less frequently occurring and considerably larger, globular, and elongated forms ranges to $>200 \mu \mathrm{m}$. The main group of small Pithonella contains two species of nearly the same dimensions and shape, differing only in the development of the calcite layers; these species cannot be distinguished with the light microscope.

This occurrence of Calcisphaerulidae in Leg 35 material is the first reported from Tertiary sediments. The range of the family is therefore extended from Late Jurassic to early Tertiary.

Pithonella bollii Rögl n. sp.

(Plate 1, Figures 1-4; Plate 2, Figures 1-4)

Description: Test hemispherical to spherical, with an extremely large circular aperture. Aperture is nearly as wide as the diameter of the test. The tests range from 45 to $70 \mu \mathrm{m}$ in diameter, with an average of $55 \mu \mathrm{m}$. The diameter of the aperture measures between 28 and 40 $\mu \mathrm{m}$. Wall formed by two layers of calcite crystals of equal thickness of 4-5 $\mu \mathrm{m}$. The wall thins somewhat in the apertural region. The outer layer consists of regular rhombohedral crystals, with the c-axis perpendicular to the surface. The dimensions of the crystals vary from 3 to $5 \mu \mathrm{m}$ length, giving the surface a rough appearance. The crystals are loosely arranged, only slightly connected, and therefore easily eroded. The inner layer is formed by slender, long crystals. The rhombohedrons extend along the c-axis and are arranged perpendicular to the surface. These crystals are tightly packed. The inner and outer surface of the inner layer are similar, consisting of small triangular crystal faces. Both layers are interlocking.

Dimensions of holotype: Diameter $56 \mu \mathrm{m}$, aperture $40 \mu \mathrm{m}$.

Locality of figured specimens: Holotype Sample 35-323-15-5, $127-$ $129 \mathrm{~cm}$; Plate 1, Figure 1; Plate 2, Figures 1-3; NMB-C 31298. Paratypes NMB-C 31 281, 31 282, 31284 (323-16-2, 77-79 cm); 31 299-31 $301(323-15-5,127-129 \mathrm{~cm})$.

Abundance: Very common, form a significant part of the fine residue.

Age of species: Early Paleocene, Danian, Globigerina edita Zone.

Lithology of type sample: Dark brown Fe-claystone with welldeveloped burrows.

Name: In honor of H.M. Bolli in recognition of his investigations on the Calcisphaerulidae.

Pithonella titanoplax Rögl n. sp.

(Plate 1, Figures 5-9; Plate 2, Figures 5-8)

Description: The hemispherical to spherical test possesses a large circular aperture. The test diameter is 50 to $70 \mu \mathrm{m}$, the average is about $60 \mu \mathrm{m}$. The aperture is between 30 and $40 \mu \mathrm{m}$ wide. Two layers of calcite crystals form a wall of about $10 \mu \mathrm{m}$ thickness. Both layers are of approximately equal thickness. The outer layer is formed by tabular plate-shaped crystals which are deformed rhombohedrons, resting with one of the long, narrow crystal faces perpendicular on the surface; the c-axis is oblique to it. These tabular crystals are arranged in an irregular criss-cross pattern with irregular open interstices. Between the network of equidimensional crystals are larger crystals of about double size (Plate 2, Figure 8). The inner layer is formed of small rhombohedrons, elongated along the c-axis, as in Pithonella bollii $\mathrm{n}$. $\mathrm{sp}$. The crystals are perpendicular to the surface and very tightly interlocked. The inner and outer surfaces have small crystal faces; the connection between both layers is weak.

Dimensions of holotype: Diameter $70 \mu \mathrm{m}$, aperture $36 \mu \mathrm{m}$.

Locality of figured specimens: Holotype Sample 35-323-15-6, 51-53 $\mathrm{cm}$; Plate 1, Figure 5; Plate 2, Figures 5, 6; NMB C 31 294. Paratypes NMB-C $31279,31283(323-16-2,77-79 \mathrm{~cm}) ; 31293,31295,31296$ (323-15-6, 51-53 cm); $31305,31308,31310,31312,31314$ (323-15, CC). 
Abundance: Very common. Tests form large part of the fine residue.

Age of species: Early Paleocene, Danian, Globigerina edita Zone. Lithology of type sample: Yellowish-brown nannofossil claystone. Name: Titanos (greek) = calcite; plax (greek) = plate; based on the characteristic outer layer of the wall with tabular calcite crystals.

Pithonella antarctica Rögl n. sp.

(Plate 3, Figures 1-6, Plate4, Figures 1-12)

Description: The large test has a spherical to ovoid and pointed shape. The aperture is variable in size; it may be large and circular (Plate 3, Figure 1) or a small pore (Plate 4, Figure 9) and in some cases it has only the beginning of an opening (Plate 4, Figures 8,11 ). The tests measure from 80 to $200 \mu \mathrm{m}$ in width and from 100 to $210 \mu \mathrm{m}$ in length. The diameter of the aperture is between 10 and $45 \mu \mathrm{m}$. In the examined specimens, the wall consists of a single layer of small crystals, which are somewhat elongated along the c-axis and perpendicular to the surface. The triangular crystal faces are smooth, edged, and sometimes have small pits (Plate 4, Figure 10). The crystals are very tightly arranged. The holotype is partially covered by larger rhombohedrons (Plate 4, Figure 2), which are believed to be secondary crystallization as there are no sharp boundaries between this layer and the wall. However, the possibility remains that they represent the relict of a second layer, not preserved in the other specimens. In addition, some platy crystals also cover parts of the wall in another, but poorly preserved, specimen (Plate 3, Figure 3; Plate 4, Figure 5). The wall thickness ranges from approximately 8 to $15 \mu \mathrm{m}$.

Dimensions of holotype: Test globular, medium sized for the species, with a large aperture; width $103 \mu \mathrm{m}$, length $116 \mu \mathrm{m}$; diameter of aperture $45 \mu \mathrm{m}$.

Locality of figured specimens: Holotype Sample $323-16-2,77-79 \mathrm{~cm}$; Plate 3, Figure 1; Plate 4, Figures 1-3; NMB-C 31 287. Paratypes NMB-C 31 285, 31 288, 31289 (323-16-2, $77-79$ cm); 31297 (323-15-6, $51-53 \mathrm{~cm}$ ) ple.

Abundance: Scarce. Only a few specimens were found in each sam-

Age of species: Early Paleocene, Danian, Globigerina edita Zone. Lithology of type sample: Dark yellowish-brown nannofossil claystone with manganese micronodules.

Remarks: The dimensions of this new species are extremely variable, ranging from forms similar to the small known species to those with extremely large tests. There is a similarity to elongated species, such as Pithonella krasheninnikovi, ranging up to $120 \mu \mathrm{m}$ in length and to $P$. fusiformis $\mathrm{n}$. Sp., having tests of over $200 \mu \mathrm{m}$ in length.

Name: Antarctica, after its occurrence in the Leg 35 samples from the Antarctic region.

Pithonella fusiformis Rögl n. sp.

(Plate 1, Figures 12-14; Plate 2, Figures 9-12)

Description: The elongated spindle-shaped test consists of one chamber. Specimens have either rounded or pointed ends. The test has normally one and sometimes two apertures. The aperture is indistinct and more or less circular. The width of the test is between 50 and 100 $\mu \mathrm{m}$, the length averages $200 \mu \mathrm{m}$, ranging from 170 to $250 \mu \mathrm{m}$. The wall of the test is formed by two layers. The inner layer is thick and composed of small elongated calcite crystals arranged perpendicular to the surface, as observed in the light microscope. The surface of the inner layer is indistinct. A thin outer layer of platy crystals covers some part of the test surface. These crystals are flat, polyhedral, and rest with a large face on the surface of the inner layer. The crystallographic form of the crystals forming the outer layer is a combination of the rhombohedron with the basis. The normally separated crystals grow together in some parts of the wall forming smooth surfaces. This outer layer seems to be a constant feature of the specimens, as seen in transverse sections, and is about $2-3 \mu \mathrm{m}$ thick. The inner layer is 3 to 4 times thicker.

Dimensions of holotype: Width $80 \mu \mathrm{m}$, length $175 \mu \mathrm{m}$; spindleshaped, pointed ends, no distinct aperture.

Locality of figured specimens: Holotype Sample $323-16-2,77-79 \mathrm{~cm}$; Plate 1, Figure 11; Plate 2, Figures 9, 10; NMB-C 31 292. Paratypes NMB-C $31290,31291(323-16-2,77-79 \mathrm{~cm})$.

Abundance: Occurs in small numbers in all samples of Leg $35 \mathrm{Da}$ nian sediments.

Age of species: Early Paleocene, Danian, Globigerina edita Zone.

Lithology of type sample: Dark yellowish-brown nannofossil claystone with manganese micronodules.

Remarks: This species differs from small Lagenidae (foraminifera) in the nature of its wall structure. At low magnification, a superficial similarity between these microfossil groups appears to exist.
Therefore it was difficult to determine to which group the specimens belonged. However, after study and recognition of the microstructures, it also became possible to distinguish the species under the binocular microscope. A relationship to Thoracosphaera prolata Bukry and Bramlette (1969), a large calcareous nannoplankton (25-50 $\mu \mathrm{m}$ ), described from the Eocene, may also be considered. $T$. prolata has an elongated, pheroidal shape and a thick wall of large, interlocking elements, giving the surface a "sculptured" appearance. The species looks similar to a calcisphaerulid, but no aperture is mentioned.

Name: Fusiformis $($ Latin) $=$ spindle-shaped, for the form of the test.

\section{COMPARISON WITH SIMILAR CALCISPHAERULIDAE SPECIES}

Direct comparison of the species described herein can only be made with the material from Leg 27 , Indian Ocean (Bolli, 1974) which was also studied and figured by SEM. All other calcisphaerulid species are described by means of the light microscope: most of them from thin-sections. As noted by Bolli (1974), reliable comparison of light microscope and SEM views is difficult.

The small globular species, Pithonella edgari Bolli and $P$. robinsoni Bolli, have affinities with the herein described $P$. bollii and $P$. titanoplax. $P$. edgari and $P$. titanoplax are from the Albian and possess walls with two layers. Both layers of $P$. edgari consist of tabular prismatic crystals of which the inner one is thinner. Tabular crystals are present only in the outer layer of $P$. titanoplax. The two layers of $P$. robinsoni are of equal thickness. On the outer layer the large prismatic crystals, intersected between smaller, tabular ones, are more frequent and more regularly distributed than in $P$. titanoplax. The inner layer of $P$. robinsoni is similar to both new species $P$. bollii and $P$. titanoplax, but the crystals are more robust.

A wall structure similar to that in P. titanoplax with elongated, interlocking, prismatic crystals which form the inner layer and tabular crystals in the outer layer, is present in the late Cretaceous species $P$. krasheninnikovi Bolli. This species is, however, distinctly elongated.

$P$. antarctica is distinctly larger than known species of Pithonella from the Indian Ocean. A similar wall structure is apparent in $P$. veeversi Bolli from the Albian and in Pithonella sp. B from the Late Cretaceous. The wall consists of a single layer in both species. The main difference, therefore, is in test size, and the occurrence of ovoid forms of $P$. antarctica.

Forms similar to $P$. fusiformis, with an elongated test, are $P$. veeversi Bolli, $P$. krasheninnikovi Bolli, and to some extent $P$. cooki Bolli. They can be distinguished from the new species by their wall structure. No other known species possesses an outer layer similar to $P$. fusiformis consisting of platy polygonal crystals. Affinities in the wall structure of the inner layer of $P$. fusiformis exist in P. cooki; however, an outer layer is missing.

\section{ACKNOWLEDGMENTS}

The author wishes to thank H.M. Bolli (Zurich) for his advice concerning the investigations of calcisphaerulids and for his helpful discussions and critical reading of the manuscript. Mineralogical and systematic problems were discussed with W. Oberholzer and K. Perch-Nielsen (Zurich). The investigations were supported by the Swiss National Science Foundation. The SEM micrographs and photoprints were kindly prepared by H.E. Franz and U. Gerber from the 
Geology Department of the Swiss Federal Institute of Technology.

\section{REFERENCES}

Bolli, H.M., 1974. Jurassic and Cretaceous Calcisphaerulidae from DSDP Leg 27, Eastern Indian Ocean. In Heirtzler, J.,
Veevers, J., et al., Initial Reports of the Deep Sea Drilling Project, Volume 27: Washington (U.S. Government Printing Office), p. 843-907.

Bukry, D. and Bramlette, M.N., 1969. Some new and stratigraphically useful calcareous nannofossils of the Cenozoic: Tulane Stud. Geol. Paleontol., v. 7, p. 131-142. 
PLATE 1

All figures $500 \times$.

Figures 1-4 Pithonella bolli Rögl n. sp.

1. Holotype, 323-15-5, 127-129 cm, NMB-C 31 298.

2. Paratype, $323-15-5,127-129 \mathrm{~cm}$, NMB-C 31 299.

3. Paratype, 323-16-2, 77-79 cm, NMB-C 31281.

4. Paratype, 323-16-2, 77-79 cm, NMB-C 31284.

Figures 5-9 Pithonella titanoplax Rögl n. sp.

5. Holotype, 323-15-6, 51-53 cm, NMB-C 31 294.

6. Paratype, 323-15-6, 51-53 cm, NMB-C 31296.

7. Paratype, 323-15, CC, NMB-C 31314.

8. Paratype, 323-15, CC, NMB-C 31308.

9. Paratype, sectioned specimen, 323-15, CC, NMB-C 31310.

Figures 10,11 Pithonella sp.; P. bollii or P. titanoplax, lacking the outer layer of the wall.

10. 323-15, CC, NMB-C 31304.

11. 323-15, CC, NMB-C 31303.

Figures 12-14 Pithonella fusiformis Rögl n. sp.

12. Holotype, 323-16-2, $77-79 \mathrm{~cm}$, NMB-C 31 292.

13. Paratype, 323-16-2, 77-79 cm, NMB-C 31290.

14. Paratype, 323-16-2, 77-79 cm, NMB-C 31291. 
PLATE 1
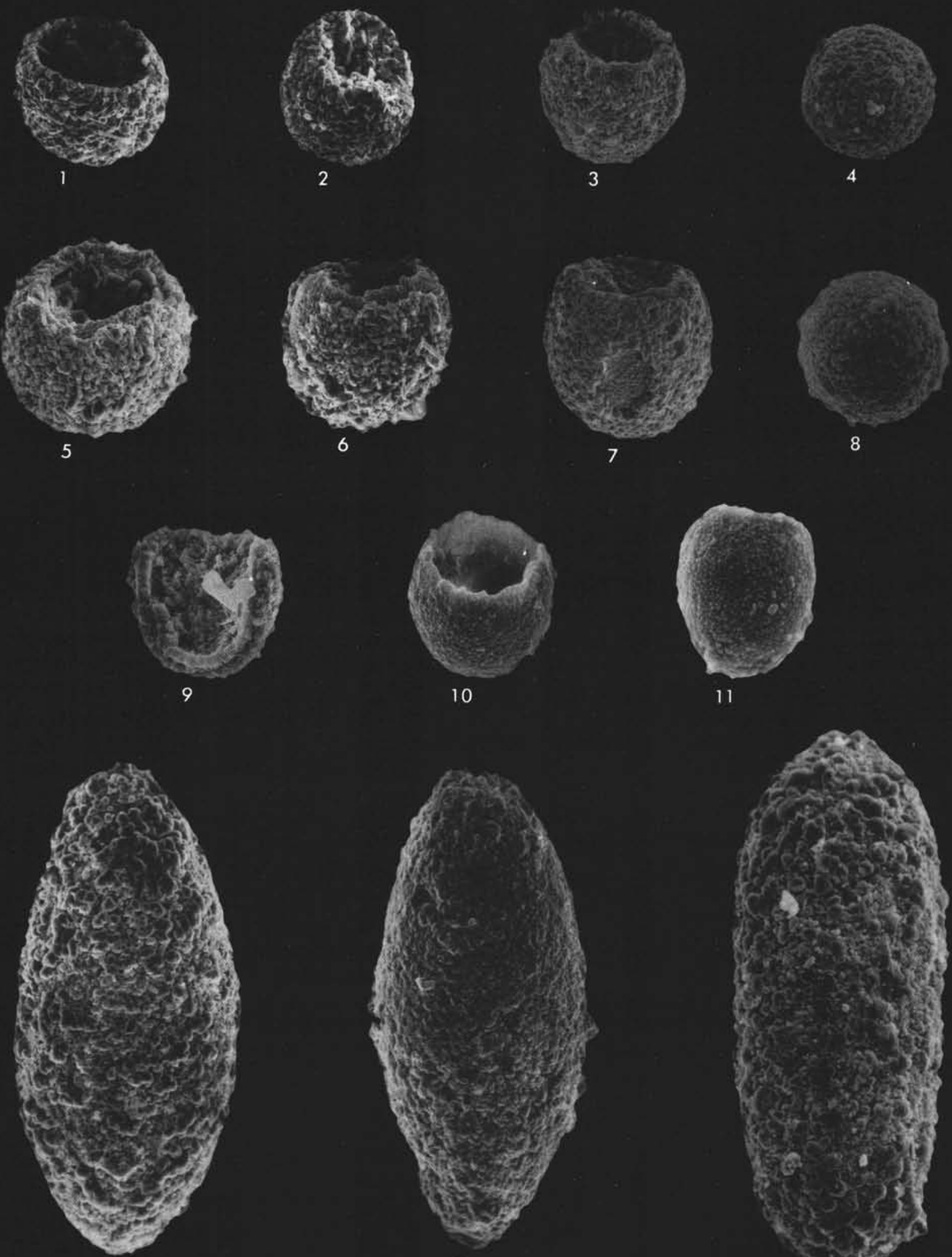

12
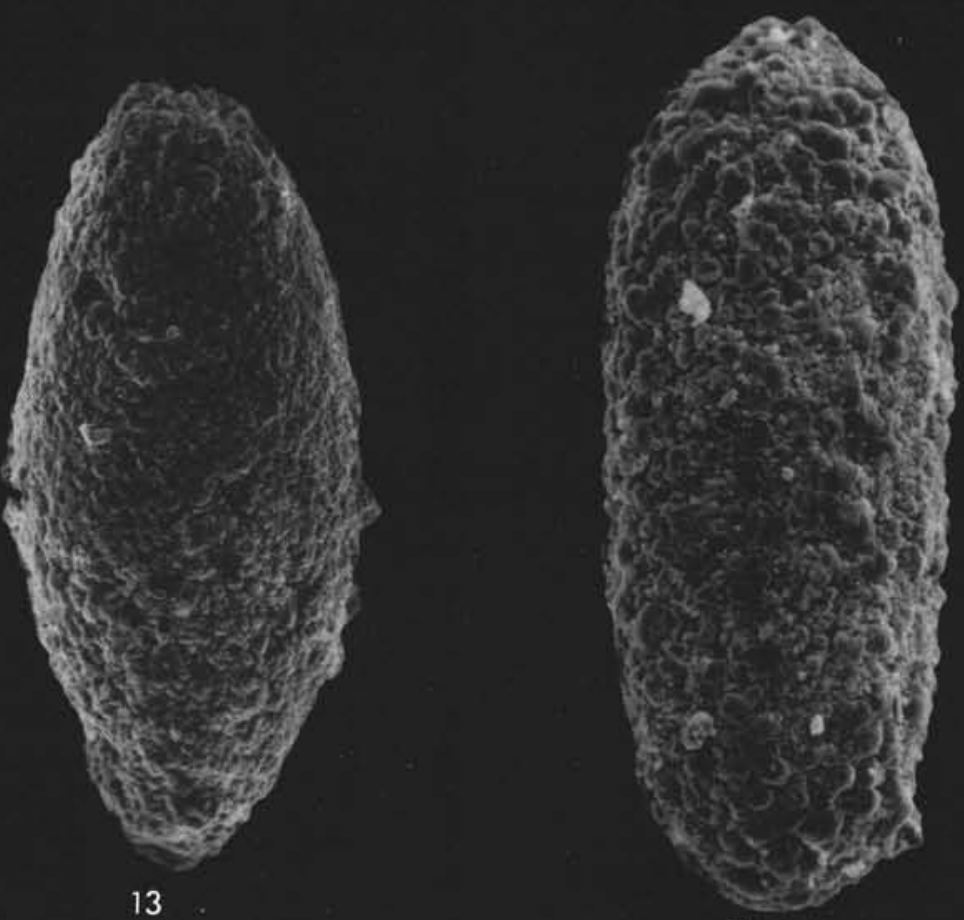


\section{PLATE 2}

Figures 1-4 Pithonella bollii Rögl n. sp.

1. Detail of Plate 1, Figure $1, \times 1500$.

2, 3. Detail of Plate 1, Figure $1, \times 2500$.

4. Detail of Plate 1, Figure 2, $\times 2500$.

Figures 5-8 Pithonella titanoplax Rögl n. sp.

5. Detail of Plate 1, Figure 5, $\times 1500$.

6. Detail of Plate 1, Figure $5, \times 2500$.

7. Detail of Plate 1, Figure $7, \times 2500$.

8. Detail of Plate 1, Figure $8, \times 2500$.

Figures 9-12 Pithonella fusiformis Rögl n. sp.

9. Detail of Plate 1, Figure 12, $\times 1500$.

10. Detail of Plate 1, Figure $12, \times 2500$.

11. Detail of Plate 1, Figure $14, \times 2500$.

12. Detail of Plate 1, Figure 14, $\times 1000$. 

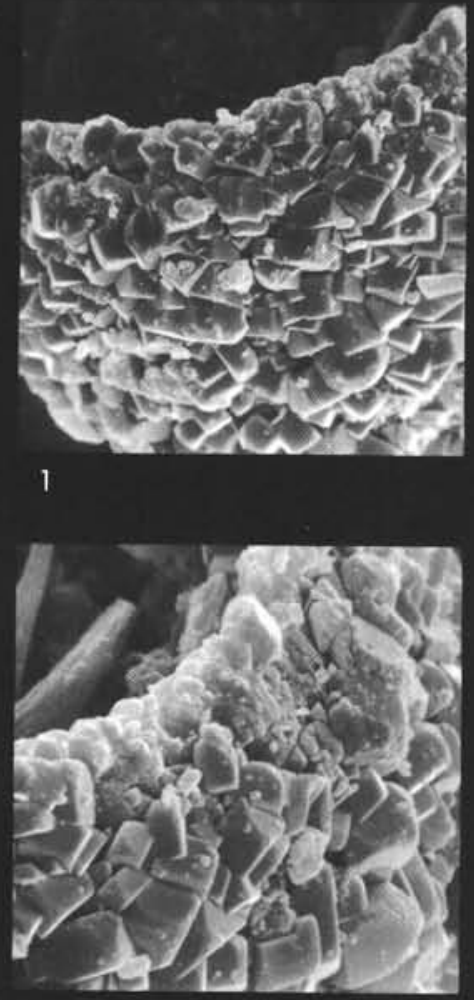

2

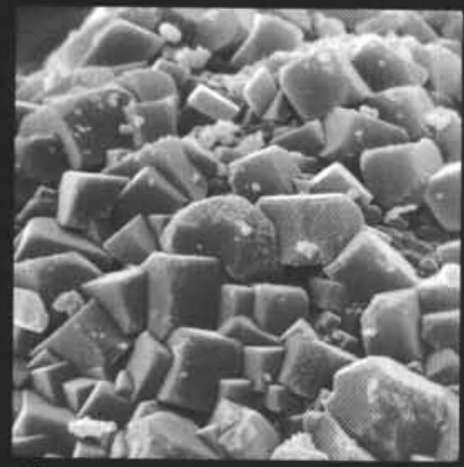

3

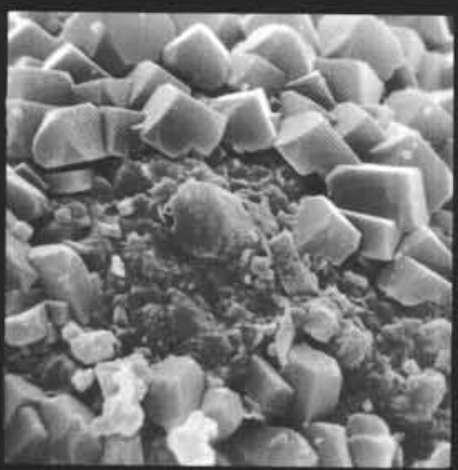

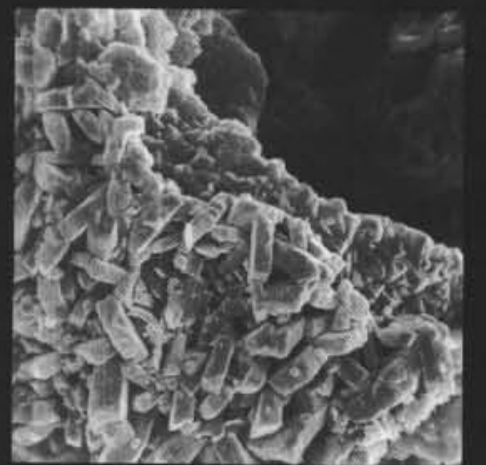

5

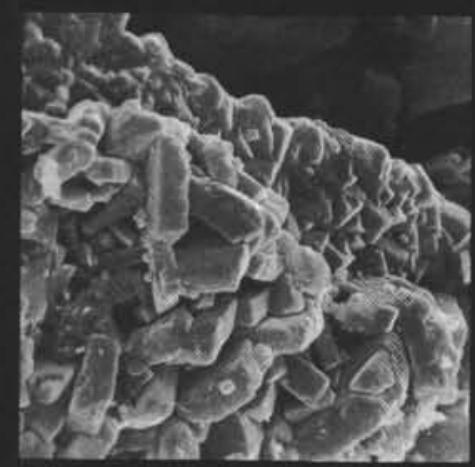

6
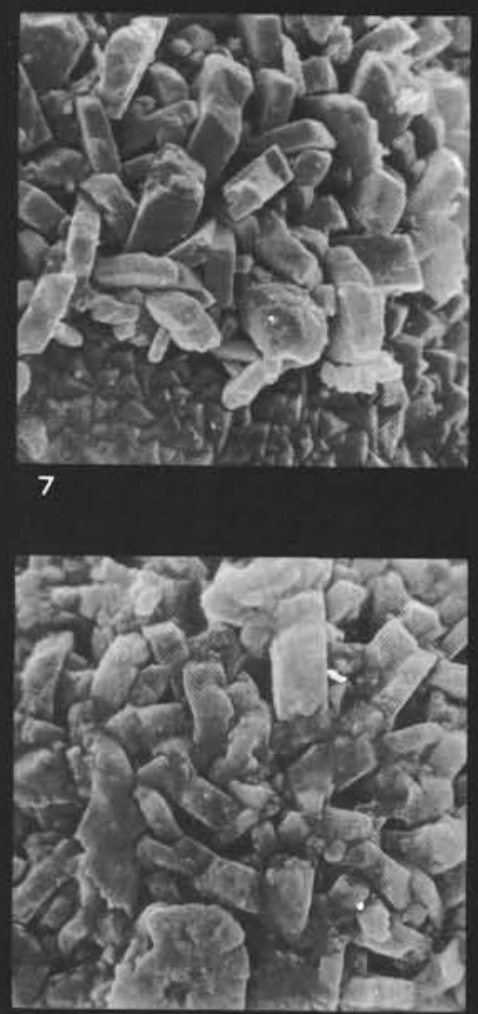

8

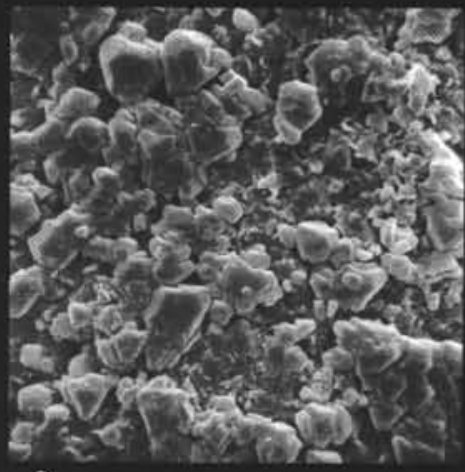

9

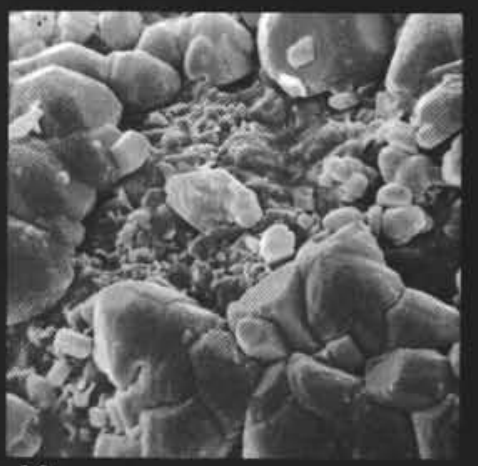

10

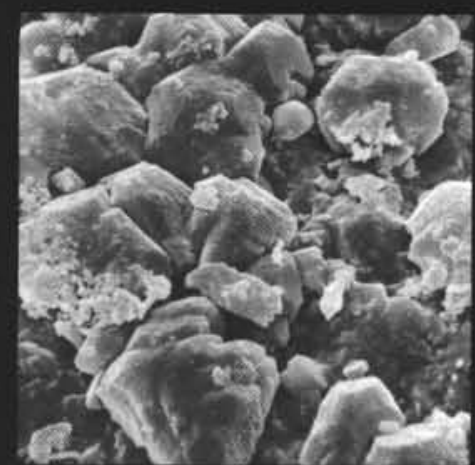

11

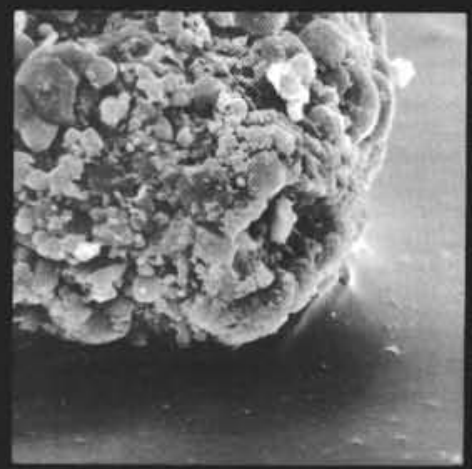

12 


\section{PLATE 3}

Figures 1-6 Pithonella antarctica Rögl n. sp.

1. Holotype, 323-16-2, 77-79 cm, NMB-C 31 287, $\times 450$.

2. Paratype, 323-16-2, 77-79 cm, NMB-C 31 286, $\times 450$.

3. Paratype, $323-16-2,77-79 \mathrm{~cm}$, NMB-C 31285 , $\times 400$.

4. Paratype, 323-16-2, 77-79 cm, NMB-C 31289 , $\times 500$.

5. Paratype, 323-16-2, 77-79 cm, NMB-C 31288 , $\times 500$.

6. Paratype, 323-15-6, 51-53 cm, NMB-C 31297 , $\times 500$. 

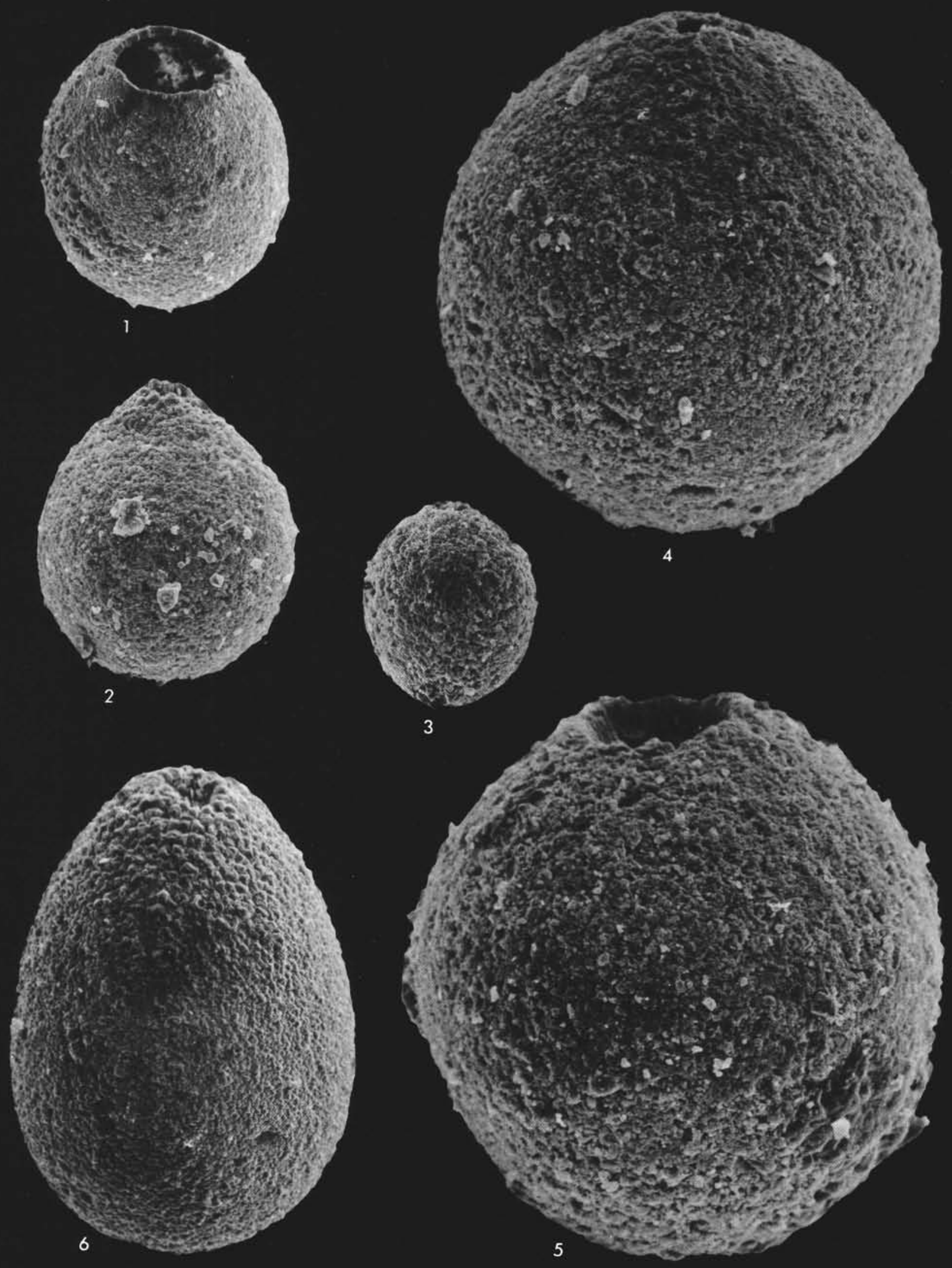


\section{PLATE 4}

Figures 1-12 Pithonella antarctica Rögl n. sp.

1. Detail of wall surface of Plate 3, Figure 1, $\times 2500$.

2. Wall surface of Plate 3, Figure 1, showing an outer layer of probably secondary calcite, $\times 1500$.

3. Detail of the aperture of Plate 3, Figure 1, showing a single-layered wall, $\times 2500$.

4. Detail of the wall surface of Plate 3, Figure 3, $\times 2500$.

5. Secondary incrustation or relict outer layer of Plate 3, Figure $3, \times 2500$.

6. Aperture of Plate 3 , Figure $3, \times 1000$.

7. Detail of Plate 3, Figure 2, $\times 2500$.

8. Beginning of aperture opening at the pointed end of specimen Plate 3, Figure 2, $\times 1000$.

9. Aperture of Plate 3, Figure 4, $\times 1000$.

10. Wall surface of Plate 3, Figure 6, showing small pits caused by etching, $\times 2500$.

11. Aperture of Plate 3, Figure 6, $\times 1000$.

12. Aperture of Plate 3, Figure 5, detail, $\times 1500$. 


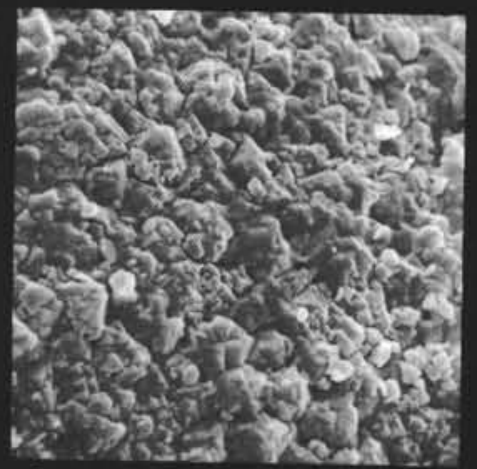

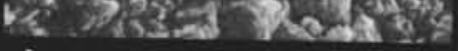

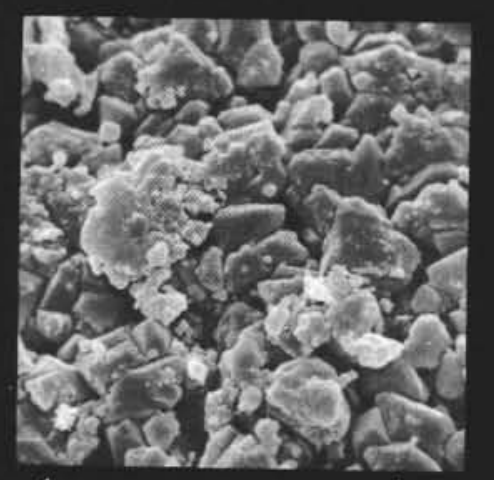

4
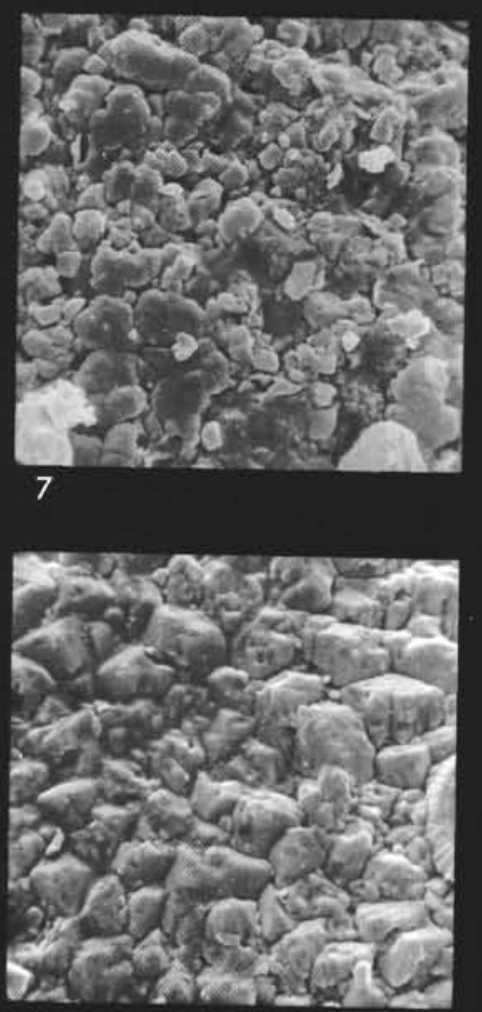
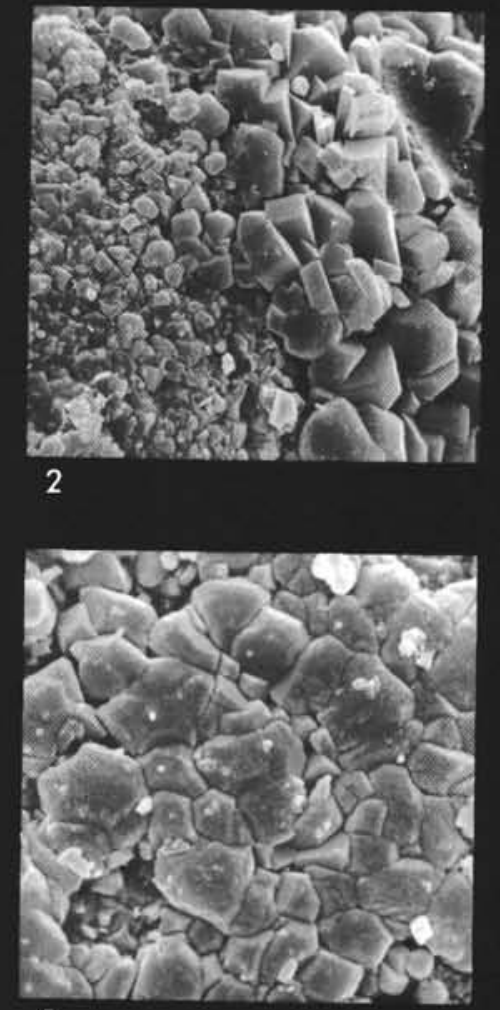

5
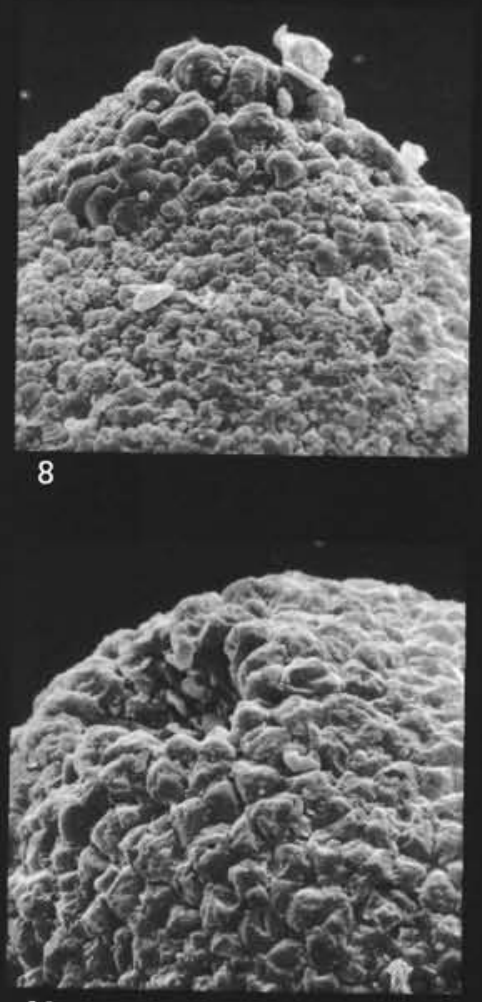

11
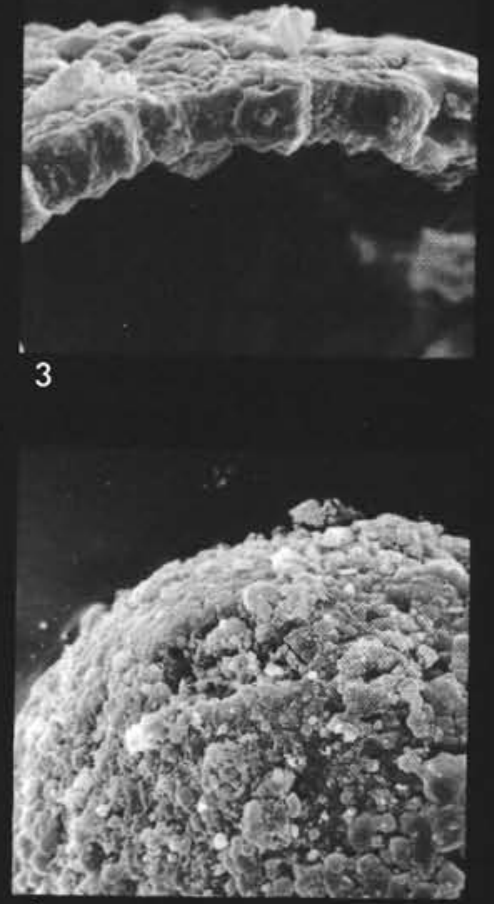

6
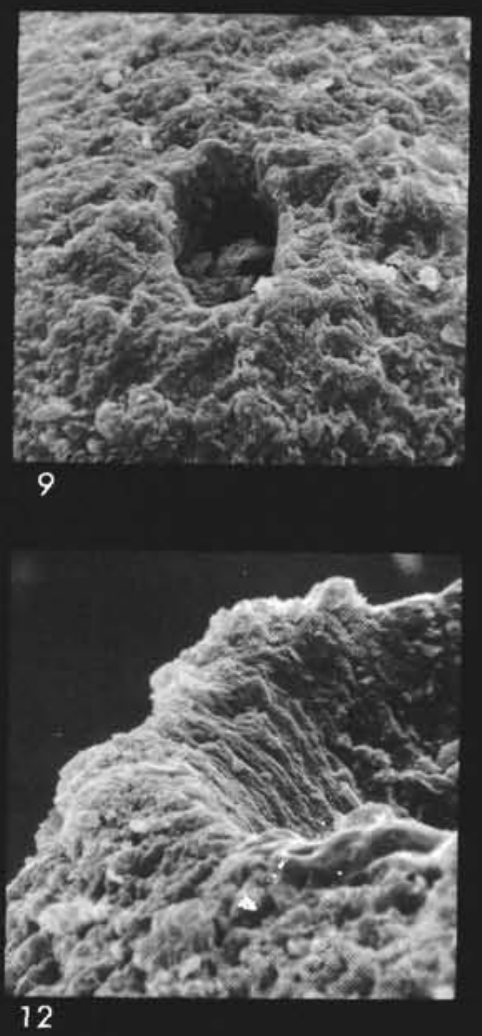